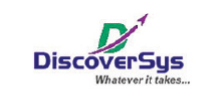

Published by DiscoverSys

\section{'I want what they're eating": College students' experiences in watching food content on YouTube}

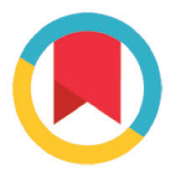

CrossMark

\author{
Dewa Ayu Mirah Ardrini, ${ }^{1}$ Dinar Lubis, ${ }^{2 *}$ Ni Wayan Arya Utami ${ }^{2}$
}

\begin{abstract}
Background and purpose: The prevalence of obesity among adolescents is increasing significantly. One of the predictors of this problem is unhealthy eating pattern due to peer and social media influence. This study aims to explore in depth the experience of college students in watching food content on YouTube.

Methods: This study used a qualitative method with a phenomenological approach. Data were obtained through in-depth interviews with ten informants and one focus group discussion with seven female students aged 18-22 years. The informants were female students who have been watching food content on YouTube for more than one year. Data collection was carried out over AprilMay 2019. Data were analyzed thematically and presented using a narrative approach.

Results: There were three themes that emerged in this study, namely the reasons for watching food content, the benefits, and

the effects of watching food content on adolescent health habits. Food content on YouTube is imagined to be educational and provides new knowledge related to food and culture in various regions of Indonesia and other countries. Watching YouTube has become a routine teen activity where they can spend one to four hours per day and can cause teens to form sedentary lifestyle. YouTube watching habits are influenced by peers and social media. It can increase adolescent appetite, thus, they more often opt for unhealthy foods.

Conclusion: Watching food content on YouTube has a positive and negative impact on adolescent health. One negative impact is that the content or influencers can cause the selection of unhealthy foods. Attractive education method should be applied in order to counteract unhealthy food content and promote healthy eating habits.
\end{abstract}

${ }^{1}$ Public Health Postgraduate Program, Faculty of Medicine, Udayana University, ${ }^{2}$ Department of Public Health and Preventive Medicine, Faculty of Medicine, Udayana University

\section{*Correspondence to:}

Dinar Lubis; Department of Public Health and Preventive Medicine, Faculty of Medicine, Udayana University;

dinar.lubis@unud.ac.id

\section{INTRODUCTION}

The prevalence of obesity among adolescents in Indonesia is reported to have increased from $10.5 \%$ in $2007,{ }^{1} 14.8 \%$ in $2013,{ }^{2}$ and $21.8 \%$ in $2018 .{ }^{3}$ Bali Province is ranked thirteenth with a prevalence of $26.4 \%$ in $2018 .^{3}$

The most important factor affecting obesity in adolescents is an unhealthy diet. ${ }^{4}$ In young women there is an association between unhealthy eating behavior and unhealthy internet content. ${ }^{5}$ One of the factors that influences adolescent eating behavior is social media and advertising. ${ }^{6}$ The majority ( $87.13 \%)$ of teenagers in Indonesia use the internet to access social media including YouTube. ${ }^{7}$ The teenagers accessed YouTube to search for information, watch food videos, look for recipes, or look for references in determining what foods to choose. ${ }^{8}$ Teenagers tend to try new products presented on social media ${ }^{9}$ that have high-calorie but low nutritional value. ${ }^{10}$

Keywords: social media, eating behaviors, teenage girls, YouTube, sedentary lifestyle

Cite this Article: Ardrini, D.A.M., Lubis, D., Utami, N.W.A.2020.'I want what they're eating': College students' experiences in watching food content on YouTube. Public Health and Preventive Medicine Archive 8(1): 4-10. D01:10.15562/phpma.v8i1.249

YouTube has become the most popular social media avenue for displaying video blog content (vlogs) in recent years. ${ }^{11}$ Social media, such as YouTube, is often used for promoting new products including restaurants. ${ }^{12}$ Restaurant management also uses YouTube as a promotional medium for their business by inviting food vloggers to inform or to review food from their restaurants and then post on their YouTube channel. Food vloggers can affect food choices of consumers or restaurants. ${ }^{13} \mathrm{~A}$ food vlogger is an influencer that can subconsciously transform adolescent eating behavior. ${ }^{14}$ Food vlogger fans who watch food content on YouTube more often spend their money on food than those who do not watch food content on YouTube. ${ }^{15}$

Research on students' experiences in watching food content has not been widely publicized in Indonesia. The purpose of this study is to explore in depth the experiences of young women in watching food content on YouTube. 


\section{METHODS}

This study uses a qualitative method with a phenomenological approach to explore in depth the experiences of adolescents when watching food content on YouTube.

Data was collected through in-depth interviews with ten informants and one focus group discussion with seven participants who had been recruited through social media and selected based on eligibility criteria, namely students who have been watching food content on YouTube for more than one year. The instruments used in this study were in-depth interview and FGD guidelines. The results of the interviews and FGDs were recorded with a USB recorder and then transcribed with a verbatim approach.

Data analysis was performed manually to identify themes that described the experiences of young women in watching food content on YouTube. The results of the interview were transcribed and combined with the field notes. The results of the transcript were highlighted (horizonalization) on words that were considered important and then given a code. Researchers obtained as many as 91 codes. At this stage, the researcher overrode all forms of prejudice (epoche/bracketing) to find the essence of phenomena in an arbitrary manner. Next, the 91 codes were grouped and classified into main sub-themes and themes. In the final stage, the researcher constructed a comprehensive description of the meaning and essence of the informant's experience.Triangulation, member checking, and peer debriefing techniques were used to obtain data validity.

This study was approved by the Ethics Committee at the Faculty of Medicine, Udayana University on 15 April 2019, Number 1011/UN14.2.2.VII.14/ LP/2019.

\section{RESULTS AND DISCUSSION}

\section{Characteristics of Informants}

Characteristics of the informants are presented in Table 1. Respondents consist of students from the Faculty of Medicine, Economics, Mathematics and Natural Sciences, Cultural Sciences, and Engineering at Udayana University. The informants were reached through snowballing technique. Most of the participants have two years experience of watching food content with a viewing duration of between one to four hours a day, and predominately watching the content when they have free time, they are hungry or eating.

The types of food content accessed on YouTube were food reviews, Korean food, culinary tours, "mukbang" (an eating shows) and autonomous sensory meridian response (ASMR) videos delivered by food vloggers in their respective styles.

Table 2 presents a summary of the results of data analysis containing three themes and seven subthemes. Three themes that emerged in this study were the reasons for watching food content on YouTube, the perceived benefits of watching food content on YouTube and the effect of food content on YouTube on healthy behavior.

\section{Reasons to watch food content on YouTube}

The information media most frequently accessed by informants was YouTube because other sources of media such as television do not present the food content that they are interested in. Most informants started watching videos on YouTube two years ago. They watched food content that was trending on social media. In addition to getting information from their peers about what to watch, sometimes they prefer to watch together.

"I started watching about two years ago, when it was trending. And at the time people stopped watching TV and started watching YouTube, mainly because on $T V$ there are no shows like this." (participant explained enthusiastically) (P4, 22 years)

"I started watching because it was trending, all social media was doing it, including on Instagram, and from there I started watching on YouTube" (P3, 22 years)

"...in the beginning I started watching because my classmate did, especially "mukbang", and then I got into it myself" (participant smiled) (P11, 19 years)

YouTube is a media of information that attracts students more than television because television does not display food content interestingly as on YouTube. Apart from having a more attractive appearance, the quote above shows that the social environment can also influence the choice of information media types and the channels being watched.

Peers have a very big influence on teenagers. They often become role models and are emulated by other adolescents, influencing their way of dressing and choice of entertainment, including social media. They also often spend time with peers so that decision making is influenced by the peers. ${ }^{6,15}$ In addition, the characteristics of teenagers who like things that are new and trendy influence which information sources they prefer. ${ }^{16}$

After watching food content on YouTube several times, the informants felt that food content on YouTube was something interesting and entertaining. They were interested in the existence of a food vlogger that brings food content 
Table 1. Characteristics of informants

\begin{tabular}{|c|c|c|c|c|c|c|}
\hline $\begin{array}{l}\text { Informant } \\
\text { Code }\end{array}$ & Faculty & $\begin{array}{l}\text { Living } \\
\text { Conditions }\end{array}$ & $\begin{array}{l}\text { Duration of } \\
\text { Watching }\end{array}$ & $\begin{array}{c}\text { Length } \\
\text { of Time } \\
\text { Watching }\end{array}$ & Watching Habits & Watched Content \\
\hline P1 (21) & Economics & $\begin{array}{l}\text { With } \\
\text { parents }\end{array}$ & 2 hours a day & 2 years & $\begin{array}{l}\text { During spare time } \\
\text { and feeling down }\end{array}$ & Street food, Korean food \\
\hline P2 (22) & Medicine & $\begin{array}{l}\text { With } \\
\text { parents }\end{array}$ & 2 hours a day & 2 years & $\begin{array}{l}\text { During spare time } \\
\text { and feeling bored }\end{array}$ & $\begin{array}{l}\text { ASMR, mukbang, culinary tours, spicy } \\
\text { food, extreme food }\end{array}$ \\
\hline P3 (22) & Medicine & $\begin{array}{l}\text { With } \\
\text { parents }\end{array}$ & 2 hours a day & 2 years & $\begin{array}{l}\text { Before going to bed, } \\
\text { when bored, biding } \\
\text { time }\end{array}$ & Mukbang, culinary tours \\
\hline P4 (22) & Medicine & $\begin{array}{l}\text { With } \\
\text { parents }\end{array}$ & 3 hours a day & 2 years & $\begin{array}{l}\text { During spare time, } \\
\text { when hungry }\end{array}$ & $\begin{array}{l}\text { ASMR, mukbang, culinary tours, spicy } \\
\text { food, food challenges }\end{array}$ \\
\hline P5 (20) & Medicine & $\begin{array}{l}\text { With } \\
\text { parents }\end{array}$ & 3 hours a day & 3 years & $\begin{array}{l}\text { While eating or } \\
\text { waiting }\end{array}$ & Mukbang, food review \\
\hline P6 (19) & Medicine & $\begin{array}{l}\text { With } \\
\text { parents }\end{array}$ & 4 hours a day & 2 years & During spare time & $\begin{array}{l}\text { Food review, mukbang, ASMR, food } \\
\text { travelling }\end{array}$ \\
\hline P7 (19) & Medicine & $\begin{array}{l}\text { With } \\
\text { parents }\end{array}$ & 4 hours a day & 2 years & During spare time & Mukbang, food review, food travelling \\
\hline P8 (19) & Medicine & $\begin{array}{l}\text { Boarding } \\
\text { House }\end{array}$ & 1 hour a day & 2 years & $\begin{array}{l}\text { During spare time, } \\
\text { before going to bed }\end{array}$ & Taste made, food review \\
\hline P9 (18) & Medicine & $\begin{array}{l}\text { Boarding } \\
\text { House }\end{array}$ & 1 hour a day & 3 years & $\begin{array}{c}\text { During spare time, } \\
\text { when hungry }\end{array}$ & Food review, mukbang \\
\hline P10 (20) & Medicine & $\begin{array}{l}\text { With } \\
\text { parents }\end{array}$ & 2 hours a day & 2 years & $\begin{array}{l}\text { During spare time, } \\
\text { when hungry }\end{array}$ & Mukbang, food review, food travelling \\
\hline P11 (19) & $\begin{array}{l}\text { Social } \\
\text { Science }\end{array}$ & $\begin{array}{l}\text { Boarding } \\
\text { House }\end{array}$ & 2 hours a day & 2 years & $\begin{array}{l}\text { When hungry or } \\
\text { bored }\end{array}$ & Street food, spicy food \\
\hline P12 (21) & Medicine & $\begin{array}{l}\text { With } \\
\text { parents }\end{array}$ & 4 hours a day & 3 years & $\begin{array}{l}\text { During spare time, } \\
\text { or while eating }\end{array}$ & Food reviews, mukbang \\
\hline P13 (20) & Medicine & Family & 3 hours a day & 2 years & $\begin{array}{l}\text { During spare time, } \\
\text { when hungry }\end{array}$ & Food reviews, mukbang \\
\hline $\mathrm{P} 14$ (19) & Business & $\begin{array}{c}\text { With } \\
\text { parents }\end{array}$ & 4 hours a day & 2 years & During spare time & Korean food, mukbang \\
\hline P15 (20) & Science & $\begin{array}{l}\text { Boarding } \\
\text { House }\end{array}$ & 1 hour a day & 2 years & At night & Korean food, streetfood, spicy food \\
\hline P16 (20) & Medicine & $\begin{array}{l}\text { Boarding } \\
\text { House }\end{array}$ & 2 hours a day & 2 years & When hungry & Carnivorous content \\
\hline P17 (18) & Engineering & Family & 3 hours a day & 2 years & While eating & ASMR, mukbang \\
\hline
\end{tabular}

\section{Table 2. Summary of data analysis results}

\section{Theme}

Reasons to watch food content on YouTube

$\begin{array}{lll}\text { The perceived benefits of } & \text { 1. Increased variety and knowledge related to food } \\ \text { watching food content on } & \text { 2. Increased appetite } \\ \text { YouTube } & \text { 3. As a lifestyle and way to socialize }\end{array}$

Effects of food content on YouTube on healthy behavior

\section{Sub-Theme}

1. The influence of the social environment (peers) and social media

2. Food content that feels entertaining

1. Eating behavior becomes unhealthy

2. Behavior that leads to a sedentary lifestyle directly to YouTube. The informants felt that the advertisements presented by food vlogger were not explicit, the content was having a high quality, and that the messages from food vloggers were easy to understand.

"Because on YouTube they are free to express what they want. The food content is well presented, up to date and well styled." (participant explained enthusiastically) ( $P 4,22$ years)

"I like it because not only does the food look amazing, I find the hosts hypnotizing. The whole experience of watching is so enticing." (participant explained seriously) (P2, 22 years) 
Today, aside from being a medium for interacting with others, social media like YouTube is also the main choice for entertainment. ${ }^{14,17}$ Food shows delivered by food vloggers on YouTube attract teenagers' attention and it is evident that teens tend to choose the food vlogger channel to be a source of information and advice. ${ }^{13,18}$ The results showed that teenagers were more receptive to influencers on YouTube compared to celebrities on television. ${ }^{19}$

Food content videos that air on YouTube can affect the desire of teenagers to try food served by food vloggers. By looking at the mouth movements, sounds produced by food, and the types of food displayed by food vloggers, it indirectly made them feel that the food was very delicious and stimulates their desire to try what is being presented, as conveyed by the informants below.

"I like to watch him eat, because he makes it look so appetizing. Especially when watching ASMR I love to hear the crunching sounds." (participant laughs) (P2, 22 years)

"I like to watch them chew, the way they eat, especially the fried food and the crunching sounds." (participant smiles) (P17, 18 years)

"I like to watch the steam rising of the food presented." (P16, 19 years)

Foods that produce a crisp sound when bitten, will indirectly make someone think about the taste of the food ${ }^{20}$, therefore, someone tends to be curious to try the food they see on YouTube.

\section{The perceived benefits of watching food content on YouTube}

Most informants revealed that watching food content on YouTube increased knowledge about food variations. Food content on YouTube is imagined to be educational and provides new knowledge related to food and culture in various regions of Indonesia and other countries.

"I got to learn more about foreign food and how to eat them. So, when I go overseas, I won't be embarrassed when eating." (participant laughed) (P3, 22 years)

"I often watch shows about foreign food, and that way I can learn about the culture as well, their eating habits and behaviours." (participant clarifies seriously) (P6, 19 years)

For teens, social media like YouTube is a place to find information related to particular foods and other things that pique their interest, including information about places they might wish to visit one day. ${ }^{17}$ Informant's knowledge also increased with regard to the eating culture of certain countries. ${ }^{8}$

Other benefits of watching food content on YouTube includes the development of taste in different foods. The informant's decision to choose menus and places to eat is often influenced by reviews from food vloggers. The recommendations given by a food vlogger is a consideration for adolescents to find out various types of food, restaurants and food stalls.

"If I watch a food review, I can then know where is a good place to get a meal, I become more selective. If the review is bad, I won't eat there." (participant explains happily) (P5, 20 years)

"I am now eating a greater variety of foods, and going to places that are popular as recommended by the reviewer." (participant explains enthusiastically) ( $P 4,22$ years)

Various studies suggest that food promotion on social media such as food vlogger reviews and the social environment often influences adolescent decisions in choosing foods that tend to be high in calories but low in nutrition. ${ }^{6,13,20}$ Food content also increases appetite, because food vloggers often display the foods they like in an appealing way.

"I like to watch Ria SW because they can tolerate really spicy foods and they review food like seafood and other things I like to eat." (participant explains imagining the food they like) (P5, 20 years)

"I used to get bored of food. But since watching while eating I have become to enjoy it more. I like to eat chocolate and watch, which then makes the chocolate taste spicy even though it isn't (participant laughs) It just feels like something is missing if I don't watch and eat at the same time." (participant explains enthusiastically) (P5, 20 years)

Reportedly YouTube has the capacity to mitigate the impact of eating disorders upon some people. Stimulus arising from watching food content can foster appetite and encourage eating. ${ }^{21}$ Seeing a variety of foods on social media can cause hunger and the desire to eat. ${ }^{8}$ Food presented on YouTube that viewers can see and hear stimulates appetite. ${ }^{22}$ Knowing where to eat and what is trendy via social media is a social capital for adolescent association. Most teenagers in this study liked to try food that was trending on social media. Discussing food that is trendy is a popular past time for youth.

"For example Mie Abang was trending in Jakarta and all food vloggers were talking about it so as soon as it opened here I tried it immediately" (P4, 22 years)

"Usually when there is a venue that is trending I will go and try it, and if it is good I will take note." (P4, 22 years)

"I get to know more, so if someone asks I can tell them about it." (P1, 21 years)

The habit of experimenting is often carried out by adolescents. In addition, adolescents also like to 
follow the behavior of their friends because of the pressure to be accepted in the peer group. ${ }^{23}$

\section{The effect of watching food content on YouTube for adolescent girls' health behaviors} One of the interesting things for informants in watching food content on YouTube is the way food vloggers enjoy food. This makes the informant want to enjoy the food and will feel satisfied if they have tried it, although they know consciously that the type of food is not healthy. For example, foods that are less nutritious such as spicy foods, oily foods, fast food, and sweet foods.

"Watching them eat makes you crave for what they are having. Because they make it look so delicious. Makes you droll and want to try what they are eating. And if you get it, it feels really satisfying." (P1, 21 years)

"They eat a lot of really unhealthy food, I love to watch them eat street food, oily food, sweet food, spicy food. I like to eat extremely spicy food. I know it isn't good for me, but I still want to try it." (participant laughs) (P7, 19 years)

Teenagers who often watch food content on YouTube always want to try foods that are recommended by food vloggers. Calorie-dense foods and street food that often appear on social media look tempting to adolescents. ${ }^{24}$ This also influences their choice of food and venue for eating. ${ }^{9,25}$

Informants in our study have been watching food content on YouTube for 2 to 3 years on a regular basis, and the longer they have watched the food content the more weight they have put on. As indicated in the quotes below.

"I definitely eat more since watching ASMR." (participant smiles broadly) (P1, 21 years)

"Portion sizes have increased as I watch them." (P5, 22 years)

"Since I started watching the content over the past two or three years I have gained at least 10 kilograms. Possibly because I eat oily food at all the time." (P4, 22 years)

"My body has changed I have gained at least five kilograms in the past two years." (P7, 19 years)

"I am chubby now, because my appetite has increased." (P15, 20 years)

For teenagers who often use social media, there is a tendency to consume food that is more than they need. This is also accompanied by choices of foods that are rich in calories, low in fiber and nutrients. ${ }^{26}$ Unwittingly this habit can cause an increase in body mass index. ${ }^{27}$ Unimpeded use of social media, especially at night, affects sleep patterns, as one informant explained:

"I often find it hard to sleep, so I watch YouTube, but sometimes that means I stay up until 2 am watching." (participant laments) (P14, 19 years). "Ugh I end up procrastinating..." (P14, 19 years) Another informant said that the habit of watching YouTube also made them lazy and idle. "I rarely exercise. It's better to watch YouTube" (participant smiles) (P1, 21 years).

The internet can have a negative effect on teen habits, such as upon sleep quality. ${ }^{27}$ Another negative impact is the emergence of idle behavior such as lack of physical activity both mild and severe. ${ }^{5,28,29}$

Our informants tend to spend time watching food content on YouTube because they believe these are addictive. Videos that are watched often have a duration of up to two hours and when they are finished, they will look for other videos.

"It is so addictive, I can watch up to six hours when I am at home, from the morning until night." ( $P 6,19$ years)

"I can watch for about two hours. I finish one then move on to another." (participant smiles) (P1, 21 years)

In a study related to YouTube's influence on teenagers, it shows that teenagers spend more time on YouTube, especially on weekends. ${ }^{14}$ YouTube offers a variety of entertaining videos that make teens unaware that their time is wasted and results in dependency. ${ }^{30}$

\section{STUDY LIMITATIONS}

This research has provided insights related to student experiences in watching food content on YouTube. However, the weakness of this study was a lack of opportunity to observe in detail the eating behavior of female college students.

\section{CONCLUSION}

Based on the results of our study, there are three main themes that describe the experience of college students in watching food content on YouTube. The influence of peers and other social environments is the main reason female students have a habit of watching food content on YouTube. The benefits felt by students while watching food content on YouTube are that their knowledge related to food culture develops, their appetite increases, and as capital to socialize with peers. Watching food content on YouTube also negatively influences their diet and creates sedentary habits.

\section{ACKNOWLEDGEMENTS}

We would like to thank the students of Udayana University who were willing to participate in this research. 


\section{AUTHOR CONTRIBUTION}

MA designed and conceived the study, gathered and analysed the data, prepared the first draft and edited the manuscript. DL and AU provided feedback and edited the manuscript.

\section{REFERENCES}

1. Ministry of Health of the Republic of Indonesia. Basic Health Research. 2007. Jakarta; 2008. p. 45-48

2. Ministry of Health of the Republic of Indonesia. Basic Health Research. 2013. Jakarta; 2013. p. 220-223

3. Ministry of Health of the Republic of Indonesia. Basic Health Research. 2018. Jakarta; 2018. p. 95-97

4. World Health Organization. Obesity and overweight [Internet]. World Health Organization. 2018 [cited 2018 Oct 22]. p. 1-8. Available from: https://www.who.int/ news-room/fact-sheets/detail/obesity-and-overweight

5. Restuastuti T, Jihadi M, Ernalia Y. The Relationship between diet and physical activity on obesity in adolescents in Pekanbaru 5 high schools. Jom Fk. 2016;3(1):9-15.

6. Deliens T, Clarys P, De Bourdeaudhuij I, Deforche B. Determinants of eating behaviour in university students: a qualitative study using focus group discussions. BMC Public Health. 2014;14:53.

7. Indonesia Internet Service Provider Association. Penetration and behavior of Indonesian internet users. [Internet]. Indonesia Internet Service Provider Association. 2017. Available from: https://apjii.or.id/ content/read/39/342/Hasil-Survei-Penetrasi-dan-PerilakuPengguna-Internet-Indonesia-2017.

8. Vaterlaus JM, Patten EV, Roche C, Young JA. \#Gettinghealthy: The perceived influence of social media on young adult health behaviors. Computers in Human Behavior. 2015;45:151-157.

9. Kustiawan R, Kuncoro IA. Faktor-faktor yang mempengaruhi keputusan konsumen dalam melakukan pembelian makanan ringan secara online [Factors that affect consumer decisions in buying snacks online]. Jurnal Hospitality dan Manajemen Jasa. 2013;1(2):351-361.

10. Holmberg C, E. Chaplin J, Hillman T, Berg C. Adolescents' presentation of food in social media: an explorative study. Appetite. 2016;99:121-129.

11. Helianthusonfri J. YouTube Marketing. Jakarta: PT. Elex Media Komputindo; 2016.

12. Widyaningrum PW. Peran media sosial sebagai strategi pemasaran pada Sewa Kostum Meiyu Aiko Malang [The role of social media as a marketing strategy in Meiyu Aiko Costume Rental in Malang]. Al Tijarah. 2016;2(2):230.

13. Hanifati AN. The impact of food blogger toward consumer's attitude and behavior in choosing restaurant. International Journal of Humanities and Management Sciences. 2015;3(3):149-154.

14. Westenberg W. The influence of YouTubers on teenagers : A descriptive research about the role YouTubers play (Thesis). University of Twente, The Netherlands; 2016.

15. Delgado J, Brad J, Balanovskiy S. Millennials eat up Youtube food videos [Internet]. 2014 [cited 2018 Oct 22]. p. 1-8. Available from: https://www.thinkwithgoogle.com/ consumer-insights/millennials-eat-up-youtube-foodvideos/
16. Yulia Trisnawati T. Fashion as a form of self-expression in communication [Internet]. Vol. III. 2011. Available from: http://nugraheniika.blogspot.com

17. Vandewater EA, Denis LM. Media, social networking, and pediatric obesity. Pediatric Clinics of North America. 2011;58(6):1509-19.

18. Nathalia TC, Par SST, Kansius C, Felicia E, Amanda IA. The influence of food blogger to the intention of consuming healthy food. In: Tourism, Gastronomy and Destination International Conference. 2015. p. 1-3.

19. Defy Media. Acumen Report : Youth Video Diet. 2015.

20. Spence C. Eating with our ears: assessing the importance of the sounds of consumption on our perception and enjoyment of multisensory flavour experiences. Flavour. 2015;4(3).

21. Tan T, Kuek A, Goh SE, Lee EL, Kwok V. Internet and smartphone application usage in eating disorders: A descriptive study in Singapore. Asian Journal of Psychiatry. 2016;19:50-55.

22. Maharani H SA, Citrakesumasari, Bahar B. Fat teen perceptions of food (Thesis). Hasanuddin University; 2014.

23. Dewi IT. Relationship of Peer groups and meeting the needs with lifestyle experiencers of high school students in Sukasari District, Bandung (Thesis). Pendidikan Indonesia University; 2015.

24. Sharma SS, De Choudhury M. Measuring and characterizing nutritional information of food and ingestion content in Instagram. In: Proceedings of the 24th International Conference on World Wide Web - WWW' 15 Companion. 2015. p. 115-6. Available from: http://dl.acm. org/citation.cfm?doid $=2740908.2742754$

25. Siregar AGS, Widodo A. The effect of social media advertising on consumer purchasing decisions (Study on Mafia Fried Rice consumers in Bandung City). In: e-Proceeding of Management. 2018. p. 1131-7.

26. Freeland-Graves JH, Nitzke S. Position of the Academy of Nutrition and Dietetics: Total diet approach to healthy eating. Journal of the Academy of Nutrition and Dietetics. 2013;113(2):307-317.

27. Arora T, Hussain S, Lam KBH, Yao GL, Thomas GN, Taheri S. Exploring the complex pathways among specific types of technology, self-reported sleep duration and body mass index in UK adolescents. International Journal of Obesity. 2013;37(9):1254-1260.

28. Fitri S. Positive and negative impacts of social media on children's social change. Naturalistic: Jurnal Kajian Penelitian Pendidikan dan Pembelajaran. 2017;118-123.

29. Kabir A, Miah S, Islam A. Factors influencing eating behavior and dietary intake among resident students in a public university in Bangladesh: A qualitative study. PLoS ONE. 2018;13(6).

30. Astutik O:, Qomariyah N. Internet usage behavior among urban youth (Thesis). Airlangga University; 2010.

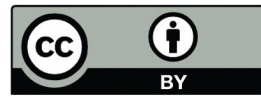

This work is licensed under a Creative Commons Attribution 